\title{
The Quality Development of Besuki Na-Oogst Tobacco in Jember Regency
}

\author{
Adhitya Wardhono ${ }^{1 凶}$, Josi Ali Arifandi², Yulia Indrawato ${ }^{3}$ \\ ${ }^{13}$ Faculty of Economics And Business, Universitas Jember \\ ${ }^{2}$ faculty of Agriculture, Universitas Jember \\ Permalink/DOI: https://doi.org/10.15294/jejak.v12i1.19359 \\ Received: October 2018; Accepted: January 2019; Published: March 2019
}

\begin{abstract}
The purpose of this study was to examine the strategies for improving the quality standardization of Besuki Na-Oogst tobacco cultivation. Data sources were obtained from the results of in-depth interviews with Besuki Na-Oogst tobacco-related stakeholders. The analytical method used was the Analytical Hierarchy Process (AHP). The results of the study showed that the success of Besuki Na-Oogst tobacco cultivation governance as a quality and export-oriented product was not only determined by good cultivation techniques but also needed to be supported by institutional patterns from upstream to downstream, starting from on-farm to off-farm. Trade and marketing are being the main priorities in the development of tobacco quality. Some of the top rankings in alternative strategies are the role of formal institutions in marketing followed by management of quality standards, determination of selling prices and market expansion occupying the priorities of all alternatives in the development of tobacco quality. These results are in line with the important role of quality in export commodities in particular in which quality will affect competitive advantage and ultimately improve the welfare of farmers and other tobacco farming actors.
\end{abstract}

Key words : Strategy; Standards and Quality; Na-Oogst Tobacco

How to Cite: Wardhono, A., Arifandi, J., \& Indrawato, Y. (2019). The Quality Development of Besuki Na-Oogst Tobacco in Jember Regency. JEJAK: Jurnal Ekonomi dan Kebijakan, 12(1), $190-103$. doi:https://doi.org/10.15294/jejak.v12i1.19359

\begin{tabular}{lr}
\hline Corresponding author : & p-ISSN 1979-715X \\
Address: Jl. Kalimantan, Number 37, Krajan Timur, Sumber & e-ISSN 2460-5123 \\
Sari & \\
E-mail: adhitya.wardhono@unej.ac.id &
\end{tabular}




\section{INTRODUCTION}

Tobacco is one of the plantation commodities that has high selling value and competitiveness in the global market. It is one of the most strategic international trade commodities in line with the increasing market demand for tobacco and tobacco products. Until now, some countries in the world such as China, India, Brazil and the United States are still the largest producers of tobacco leaves in the world. The largest production in 2016 in the world is China that it reached 2,806,770 tons, followed by India with the highest production in 2016 reaching 761,318 tons and Brazil with 675,545 tons. Meanwhile, Indonesia was in the fifth rank from the six largest tobacco producer countries in the world with the production reaching 196,154 tons in 2016 (http://www. fao.org/faostat). In China, tobacco production is a lucrative business that can absorb 17 million workers. Whereas, in Indonesia, tobacco commodities are very potential proved by the number of requests for cigarettes. The concentration of production is found in several regions such as East Java, West Nusa Tenggara and Central Java.

Besuki Na-Oogst (Bes-NO) tobacco is a type of tobacco that has a high export potential as a raw material for making cigar. The quality of BesNO tobacco produced by Indonesia is one of the best in the world, namely in the second rank in the world after Brazil and almost 90 percent is favored by international export markets such as premium markets in Germany, Switzerland, the Netherlands, the United States and China (Utami et al, 2014). The development of cigar tobacco in Indonesia is concentrated in three regions, namely Deli (North Sumatra), Klaten and Besuki District (Djajadi, 2008).
Jember Regency is one of the regions in East Java Province which has considerable plantation potential, especially tobacco, and is known as Tobacco City because of its cigar production which can break through to the export market. Tobacco Besuki Na-Oogst (NO) cigar developed in Jember Regency since the 1850 os and became a prominent commodity as a driver of the regional economy. In the 1970s and 1980s, Besuki NO tobacco area ranged from 15-20 thousand hectares with production of around 12-15 thousand tons per year. In general, the Besuki NO tobacco planting area is managed by farmers reaching 81.88 percent with an area of $8,654.65$ ha and partly managed by State-Owned Enterprises (BUMN) and private companies (Basoenando, 2001; Soetriono, 2014). However, due to the impact of climatic anomalies and the Mount Raung ash natural disaster in the middle of 2015, the number of $\mathrm{Na}$-Oogst tobacco production decreased, especially in East Java. Crop failure was followed by a decrease in the area of Besuki Na-Oogst tobacco planting area, especially in the Jember (BPS, 2016).

The decline in the selling value of tobacco is the significance of the causes of land constriction due to decreasing standard and quality of tobacco, while tobacco prices are determined by standard and quality (Keyser and Juita, 2005; Negri and Porto, 2016; Zhang et al., 2015). It was recorded that $\mathrm{Na}-\mathrm{Oogst}$ tobacco exports experienced a decline in 2015, namely 6,423 tons from the previous year which were as many as 6,866 tons, but in 2016 it increased again to 6,586 tons (UPT PSMB Tobacco Institute, 2017). The definition of tobacco quality in this era has experienced many changes and progress along with the demands of the international market. Conventionally, tobacco quality is defined as a statement of physical (easily measurable), organoleptic (subjective) chemical 
properties in a non-standardized tobacco product. Usually the quality of tobacco is expressed in the form of grading / special signs on tobacco products in each producer in each of the different regions.

Abdallah (1972) defines that the quality of tobacco as a combination of physical, chemical, organoleptic and economic properties that cause tobacco to be suitable or not for certain purposes. Tobacco quality is also defined as a combination of all chemical and organoleptic properties that can be transformed by companies, traders, or economical smokers and viewed in terms of acceptable taste. In addition, Tso (1972) states that quality has a relative nature which can change due to the influence of people, time, and place. Therefore, it can be concluded that quality is determined by differences in the interests of each party in accordance with the objectives based on physical, chemical and sensory aspects.

The development of Besuki Na-Oogst (BesNO) tobacco cultivation as a product that prioritizes quality is faced with the complexity of the problems of uncertainty about climatic anomalies, pest and disease attacks and the implementation of cultivation technology. Difficult prediction of climate change causes many farmers to experience crop failures with low quality tobacco leaves. Meanwhile, in terms of global market demand, the challenges of an increasingly dynamic and competitive global economy require tobacco farmers to implement Good Tobacco Practice (GTP) and in line with quality standards as well as establish good and mutually beneficial institutional patterns (Feirman et al., 2017; Keyser and Juita, 2005; Zhang et al., 2015).
The success of Besuki Na-Oogst tobacco cultivation governance as a good quality and export-oriented product is not only determined by good cultivation techniques, but also needs to be supported by institutional patterns which are present among business actors and also policy makers, in this case is the government. Institutional strengthening in Besuki Na-Oogst tobacco cultivation must be carried out integrally from upstream to downstream by involving every component and space of interaction in each link. This study aimed to examine the strategies to improve the quality standardization of Besuki Na-Oogst tobacco cultivation in order to be able to compete with exports.

\section{RESEARCH METHOD}

The type of data used in this study were primary data and secondary data as supporting data. The secondary data were from the relevant agencies, including the Provincial and District / City Statistic Centers, Provincial and District Municipal Plantation Offices, UPT of Quality Testing and Certification of Jember Tobacco Institutions, Fiber Crop Research Institute (Balitas), Tobacco Associations, and other relevant agencies. For more, the primary data were in the form of perception data of people who are experts or who understand the problems of Besuki Na-Oogst tobacco. The sampling technique was done by purposive sampling with in-depth interview techniques through Focus Group Discussion (FGD) on tobacco-related stakeholders, especially Besuki Na-Oogst, among others, Na-Oogst tobacco farmers, Na-Oogst tobacco exporters, academics, tobacco observers, UPT PSMB Tobacco Institutions, local government and other relevant stakeholders. 
The analytical method used was Analytical Hierarchy Process (AHP). The reason for using this method was to obtain strategy arrangements for developing the quality of the Besuki Na-Oogst tobacco which involved various indicators in a complex and manner (Triantaphyllou and Mann, 1995; Kasperczyk and Knickel, Without Years). In the AHP method, decision making was done by pairwise comparisons without changing the position of the criteria arrangement (Chen et al., 2010; Nezhad and Rezaei, 2015; Romeijn et al., 2016). There are three basic principles in AHP, namely decomposition, comparison of judgments (Comparative Judgments) and synthesis of priorities. With the existence of these three basic principles, it was expected that a consistent structure of decisions could be obtained so that it can be used to develop the Besuki $\mathrm{Na}$ Oogst tobacco quality development strategies.

The Analytical Hierarchy Process is a decision support model developed by Thomas L. Saaty. This decision support model will describe multi-factor problems or complex multi criteria into a hierarchy. According to Saaty (1993), hierarchy is defined as a representation of a complex problem in a multi-level structure where the first level is a goal, followed by a factor of level, criteria, sub criteria, and so on down to the last level of the alternative. With hierarchy, a complex problem can be broken down into groups which are then arranged into a hierarchical form so that the problem will appear more structured and systematic.

In the AHP method, the following steps are taken (Kadarsyah Suryadi and Ali Ramdhani, 1998). The first step, it defines problems and determine the desired solution. In this stage, researchers try to determine the problems to solve clearly, in detail and easily understood. From the existing problems, solutions that might be suitable for the problem are determined. Additionally, the solutions for problems may amount to more than one. After that, these solutions are further developed in the next stage. Create a hierarchical structure that starts with the main goal. After arranging the main goal as the top level, a hierarchy level will be arranged below, namely the criteria that are suitable to consider or assess the provided alternatives and determine these alternatives. Each criterion has a different intensity. The hierarchy is then continued with sub-criteria (if possible). Make a paired comparison matrix that describes the relative contribution or influence of each element to the goal or criteria that are above it. The matrix used is simple, has a strong position for a framework of consistency, obtains other information that may be needed with all possible comparisons and is able to analyze the sensitivity of the overall priority for changing considerations. The approach to the matrix reflects the dual aspects of priorities, which are dominating and dominated. Comparison is based on judgment from decision makers by assessing the importance of an element compared to other elements. To start the pairwise comparison process, a criterion from the top level of the hierarchy is chosen; For example, $\mathrm{K}$ and then from the bottom level of the elements to compare are taken, such as E1, E2, E3, $\mathrm{E}_{4}$, E5. Perform pairwise comparisons so that the total number of judgments is $\mathrm{n} \times[(\mathrm{n}-1) / 2]$, with $\mathrm{n}$ is the number of elements compared. The results of the comparison of each element will be a number ranged from 1 to 9 showing a comparison of the importance of an element. If an element in the matrix is compared to itself, the results of the comparison are given a value of 1. Scale 9 has been proven to be acceptable and 
can distinguish intensity between elements. The results of the comparison are filled in cells that correspond to the elements compared. Calculate eigenvalues and test their consistency. If it is not consistent, the data retrieval is repeated. Calculate the eigenvector of each paired comparison matrix which is the weight of each element for prioritizing elements at the lowest hierarchy level until it reaches the goal. Calculations are done by summing the values of each column of the matrix, dividing each value from the column by the corresponding column to obtain the normalization of the matrix, and adding up the values of each row and dividing it by the number of elements to get the average. Check hierarchical consistency. The expected consistency is near perfect so as to produce a decision that is almost valid. Although it is difficult to achieve perfect, the consistency ratio is expected to be less than or equal to $10 \%$.

Analytical Hierarchy Process is based on three basic principles, namely decomposition with this principle, complex problem structures are divided into hierarchical sections. Objectives are defined from general to specific. In the simplest form, the structure will be compared to the objectives, criteria and alternative levels. Each alternative set may be further divided into more detailed levels, covering more of the other criteria. The top level of the hierarchy is a goal consisting of one element. The next level may contain several elements, by which the elements can be compared, have almost the same interests and do not have too much difference. If the difference is too large a new level must be made. Comparison comparative judgments. With this principle, pairwise comparisons of all existing elements will be built in order to scale the relative importance of the elements. Assessment produces a rating scale in the form of numbers. Comparison in pairs in form of a matrix, if combined will produce priority. Priority Synthesis. Priority synthesis is done by multiplying local priorities with the priority of the relevant criteria at the top level and adding them to each element in the criteria-influenced level. The results are combined or known as global priorities which are then used to weight the local priorities of the elements at the lowest level in accordance with the criteria.

Analytic Hierarchy Process is based on 3 main axioms, namely reciprocal axiom. This axiom states if PC (EA, EB) is a paired comparison between element $\mathrm{A}$ and element $\mathrm{B}$, by calculating $C$ as the parent element indicates how many times more property has element $A$ to $\mathrm{B}$, then $\mathrm{PC}(\mathrm{EB}, \mathrm{EA})=1 / \mathrm{PC}(\mathrm{EA}, \mathrm{EB})$. For example, if $A$ is 5 times greater than $B$, then $B=$ 1/5 A. Homogeneity Axiom. This axiom states that compared elements do not differ too far. If the difference is too large, the results obtained contain a high error value. When hierarchy is built, we must try to arrange the elements so that the element does not produce results with low accuracy and high inconsistencies. Dependency Axioms. This axiom states that the priority of elements in the hierarchy does not depend on the element level below it. This axiom allows us to apply the principle hierarchical composition.

\section{RESULTS AND DISCUSSION}

Besuki Na-Oogst tobacco is an export product specifically made for cigars. Compared to other types of tobacco such as Vor-Oogst tobacco, Na-Oogst tobacco requires a special crop management pattern with relatively higher production costs. This is because of the 
increasingly dynamic and high demands of the market, especially on quality in accordance with international standards.

$\mathrm{Na}$-Oogst Tobacco is a quality product that requires special treatment ranging from the use of seeds, fertilizers and pesticides that are not excessive and requires caution in handling during harvest and post-harvest, at the time of transportation and curing space which must meet special standards. As a result, when compared to other types of tobacco, NO tobacco requires a greater business cost. Besuki NO Tobacco specifically only develops in Jember Regency and a small part in Bondowoso Regency. The planted variety is $\mathrm{H}_{3} 82$ which has advantages for farmers, namely long and wide leaves, small and fine leaves or veins and good leaves quality. Meanwhile, fertilizer needs also vary by region in Jember Regency. The northern part of Jember area needs KS fertilizer around 90-120 kg N / ha, the central part of Jember requires $60 \mathrm{~kg} \mathrm{~N} /$ ha for KS and Urea fertilizer as a starter with the result of tobacco leaves of $1,329 \mathrm{~kg} / \mathrm{ha}$ and 66.1 percent dek-omblad quality. Further, the southern part of Jember requires a dose of $250 \mathrm{~kg} \mathrm{~N} /$ ha from Urea fertilizer. Geographical differences in regions in Jember Regency have implications for differences in tobacco management systems (Sholeh, 200o). The southern part of Jember requires cultivation technology, namely $\mathrm{N}$ fertilization, irrigation and the initial age of harvest that is suitable for dekblad and omblad production with the result of tobacco leaves reaching $1,943 \mathrm{~kg} /$ ha with the quality of dekomblad 90.8 percent or $1,764 \mathrm{~kg} / \mathrm{ha}$. The southern region of Jember has water availability, temperature and air humidity and high light intensity.
The potential of Na-Oogst tobacco as the basic ingredient of export-oriented cigars has provided a special attraction for farmers and has even become a prestige to always cultivate $\mathrm{Na}$ Oogst tobacco. Some Besuki Na-Oogst tobacco species are traditional Besuki Na-Oogst tobacco (BesNOTRA) which are planted in the middle of the dry season and harvested in the rainy season, early planting Besuki Na-Oogst tobacco (BesNOTA) and shade tobacco (TBN) planted at the end rainy season and harvested in the dry season. BesNOTRA and BesNOTA tobacco are usually cultivated by farmers, while Shrimp Tobacco (TBN) is generally cultivated by exporters given the high production costs.

$\mathrm{Na}$ Oogst tobacco has various types of process. The Na Oogst tobacco types identified by SNI, Indonesia National Standards are Tobacco for cigars (SNI o1-0611-1989), Besuki Tobacco (SNI 01-3941-1995), Vorstenlanden Tobacco (SNI o1-3940-1995), Deli Tobacco (SNI o1-4402- 1996), Connecticut Shade Tobacco (TBN) (SNI o1-7134-2006), and besuki Cigar Tobacco-part 1: Asalan (SNI 7882.1: 2013).

The development of tobacco quality in order to be able to have competitive advantages both in the domestic market and in the international market is determined by the cultivation process starting from on-farm and off-farm. In terms of aquaculture, there are several cultivation activities, namely crop management related to Site Specific Tobacco Land Management (SSTLM) technology. In some types of tobacco, cultivation guidelines have been made in the form of Good Tobacco Practices (GTP). Whereas, from the off-farm side, market behaviors to inspect are supply and demand, the way, form and time of presentation, policies of sellers and buyers, marketing channels, and approaches. 
As an effort to develop the quality of Besuki Na-Oogst tobacco, there are various complex aspects which are related to each other in the process of Besuki Na-Oogst tobacco cultivation. Hence, strategies for developing the quality of tobacco for Besuki $\mathrm{Na}$-Oogst are needed with the aim of covering all aspects and are structured in a structured manner. By using AHP analysis techniques, an in-depth review was carried out related to the development of the strategies for developing the quality Besuki Na Oogst tobacco. This aimed to capture perceptions of tobacco experts by covering several levels of criteria arranged in a hierarchy as showed in Figure 1.

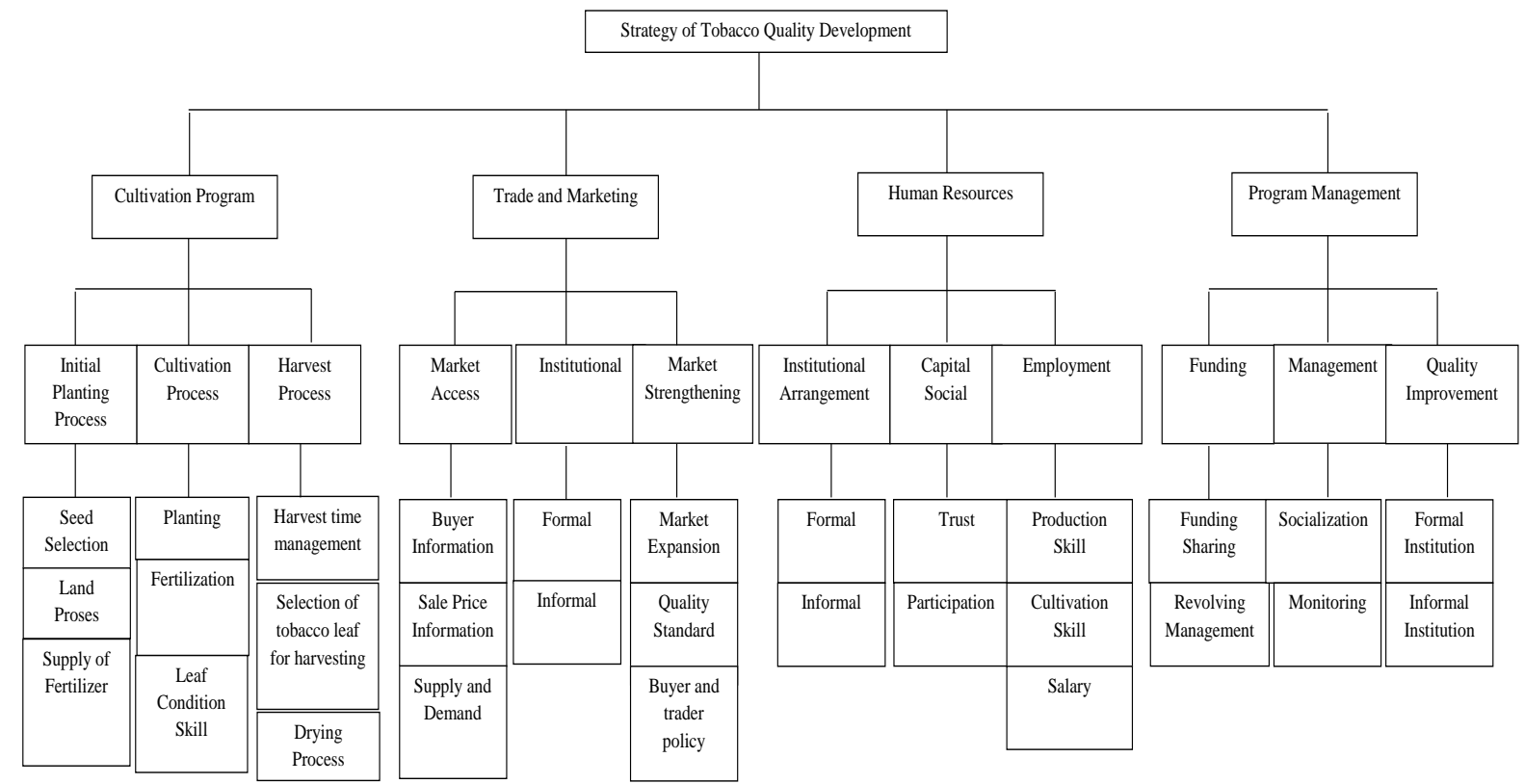

Figure 1. Tobacco Quality Development Strategies

Figure 1 shows the hierarchy of Besuki Na-Oogst tobacco quality development strategies. It is divided into four (4) criteria levels with each level having three (3) aspects and each aspect having criteria. The first level or criterion for improving the quality of tobacco Besuki Na-Oogst is the management of tobacco cultivation, followed by trade and marketing, human resources, and program management.

Figure 2 shows that in developing tobacco quality the most preferred aspect is the aspect of human resources with a weight of 32 percent, management of tobacco cultivation by 28 percent, management and marketing by 27 percent and the smallest is the management of programs from the government and stakeholders with the portion of 13 percent.

The development and improvement of the quality of human resources in the process of developing tobacco quality has a very important role (Claudia et al., 2013; D. Rokhmah, 2014; D. anf K. Rokhmah, 2014).

Improving the quality of human resources not only plays an important role in the cultivation process but also in the entire chain of tobacco farming activities, including farmers, traders, entrepreneurs, the government and other stakeholders. Efforts that can be done to improve the quality of human resources in 
tobacco farming include training the role of traders. Intensive persuasive socialization of farmers, entrepreneurs and the government in the form of training, workshops, seminars, comparative studies and other activities. Professional business skills training for all stakeholders.

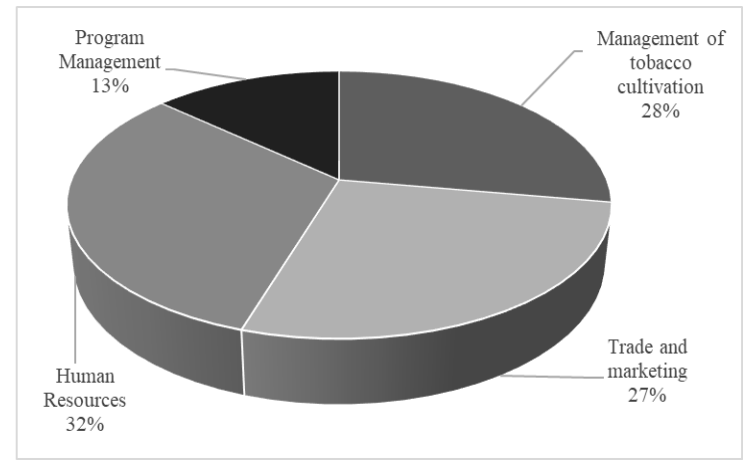

Figure 2. The Portion of Development Priorities for Tobacco Quality

Note: Consistency index 0.05

Source: Primary data, AHP processed, 2017

On the criteria of human resources, the prioritized aspects are in the development of the quality of tobacco Besuki Na-Oogst namely employment, institutional and social capital. These are showed in Figure 3 below:

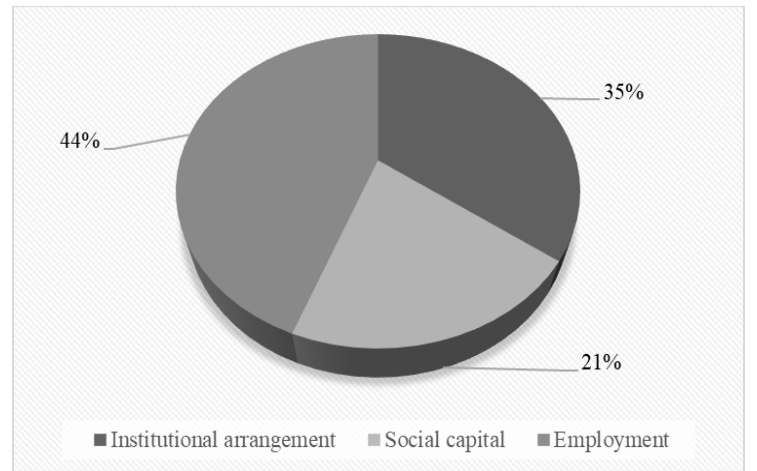

Figure 3. The Priority Portion of Sub Criteria for Human Resources

Source: Primary data, AHP processed, 2017

Of the entire chain of farming activities, the stages that absorb the largest labor force are at the stage of tobacco cultivation. Absorption of labor in the process of tobacco cultivation is as much as 200,000 families, with the number of workers in the field of $\pm 2,000$,ooo people. Most of these workers work as farm laborers with very low wages and low productivity. Meanwhile, the number of workers absorbed in the industry and others is \pm 15,000,000 as un-skilled labor. On the other hand, from the results of an estimate there were 18 million people who were totally or partially dependent on tobacco farming activities.

However, the labor law has been regulated in Act No. 13/2003 concerning employment states that 1) it is prohibited from employing children, 2) paying labor and giving rights according to applicable laws and regulations and 3) providing labor safety equipment.

Institutional strengthening in aspects of the quality of human resources was carried out by forming farmer institutions through farmer groups or cooperatives by using the principle of partnership and revolving funds for the development of tobacco farming, forming and developing revolving fund management of POKJA that originates from cigarette excise in order to facilitate partnerships and foster farmers, and the establish farmer associations to improve bargaining power.

The second criterion for developing tobacco quality is the management of tobacco cultivation. From the entire process of $\mathrm{Na}$-Oogst tobacco cultivation, the top priority to improve tobacco quality is the cultivation process, the big harvest process, and the annual start process as showed in Figure 4.

The good Besuki Na-Oogust tobacco cultivation technique is to use superior seeds, and all aspects of tobacco cultivation are fulfilled well with good weather. Through these method, good quality tobacco is expected to produce, 
especially in dealing with pests and viruses both during cultivation and storage in the processing warehouse.

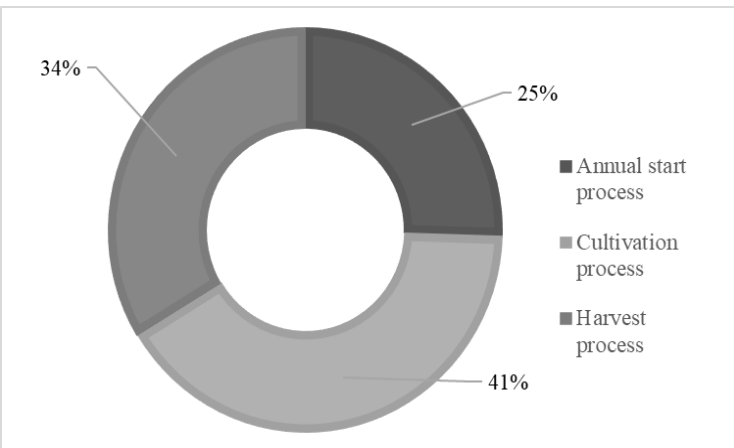

Figure 4. The Priority Portion of Sub Criteria for Tobacco Cultivation Management

Source: Primary data, AHP processed, 2017

The process of tobacco cultivation includes several stages of activities, namely: (1) planting preparation which includes soil processing, soil enrichment, and seed dispersal; (2) pay attention to planting factors such as: planting time and spacing in planting seeds; (3) maintenance that needs to take into account, among others: soil maintenance, fertilization, irrigation and drainage; (4) eradication of pests and diseases and (5) aspects to pay attention during harvesting time: the acidity of tobacco, the number of leaves picked, and the time of picking. The process during cultivation is a top priority in the development of tobacco quality, namely achieved the weight value of 39 percent followed by the planting process and the annual start process. Cultivation processes that are in accordance with Good Tobacco Practices (GTP) include the use of superior seeds, selection and processing of land, planting, maintenance and eradication of pests and diseases which are supported by good weather. This practice is done with hope to obtain good quality. The biggest disturbance in achieving good quality is the presence of pests and diseases both in plants and in processing warehouses.

In the cultivation process, there are several obstacles that affect the value of tobacco exports. The obstacles are as follows. The average production cost of tobacco leaves is higher compared to foreign production. Current exports had low quality and only sold the lower leaves of tobacco. Productivity of good quality tobacco leaves (middle and upper leaf position) is relatively low compared to abroad. Limited supply of pure and high quality of seeds for tobacco farmers caused by the unavailability of an institution which regulates the system of stocking, supervision, and distribution of tobacco seeds.

The unavailability of accurate weather forecast information caused by no integrated climate and weather information system. Limited domestic tobacco production which is only in one planting season which further disrupts the continuity of supply to the market. The tendency of non-intensive land management, fertilization that is less than the standard / dose requirement, undone pruning is still often found in the tobacco production process in Indonesia. The quality standards of tobacco which are free from pesticide residues and Non Tobacco Related Materials (NTRM) have not been widely fulfilled because generally pest control is still chemically using chemical pesticides / decis / cakron / dursban. Even, many countries have required pesticide residual thresholds. In the Coresta list there are more than 100 residual thresholds of active ingredients that are prohibited. Decrease in the amount of 
domestic tobacco production due to a decrease in the amount of tobacco plantations caused by land conversion or change for nonagricultural purposes.

The on-farm process in tobacco farming activities plays a very large role in the formation of tobacco quality which will later determine its price of food in the market (Onder, 2010; D. Rokhmah, 2014). In terms of quality, there needs to be a more diverse differentiation of Besuki Na-Oogst tobacco. The same as other types of tobacco which have different quality differentiations and have relatively cheaper selling prices. Meanwhile, in terms of price, Besuki NaOogst tobacco has a higher selling price, even the selling price of dry Na-Oogst Besuki almost has the same level as imported tobacco that has undergone processing. This is because Besuki Na-Oogst tobacco is one of the export commodities which is very vulnerable to quality and price competition. Further, the off-farm, trade and marketing processes had a considerable contribution in the process of determining tobacco prices and the income of tobacco farmers. On the criteria of trade and marketing, the top priority in developing the quality of tobacco Besuki NaOogst, is market access, followed by market strengthening and the last is institutional as showed in Figure 3.5. In terms of aspects of market access, the Besuki Na Oogst tobacco marketing chain ended with certain manufacturers, entrepreneurs and exporters as final buyers.

When viewed from the market structure, Besuki Na-Oogst tobacco marketing chain can be categorized into oligopsony market. In this position the bargaining power of farmers is very low. This is caused by the quality of tobacco that the market demands cannot be fully fulfilled by farmers. The problem that often arises in the process of trade and marketing is excess inventory. This problem is often faced by farmers and exporters when facing the final buyer. In order to respond to demands and technical requirements in the international market, there is a need for institutional strengthening of all agents in the Besuki Na Oogst tobacco farming. This is aimed to accommodate various interests of farmers and provide knowledge and skills to farmers as well as other stakeholders. Alternatively, in the context of improving the quality of Besuki Na-Oogst tobacco and expanding market access, especially internationally, there is a need for intensive human resource education and development and strong coordination at all levels of the Besuki $\mathrm{Na}$ Oogst tobacco farming business.

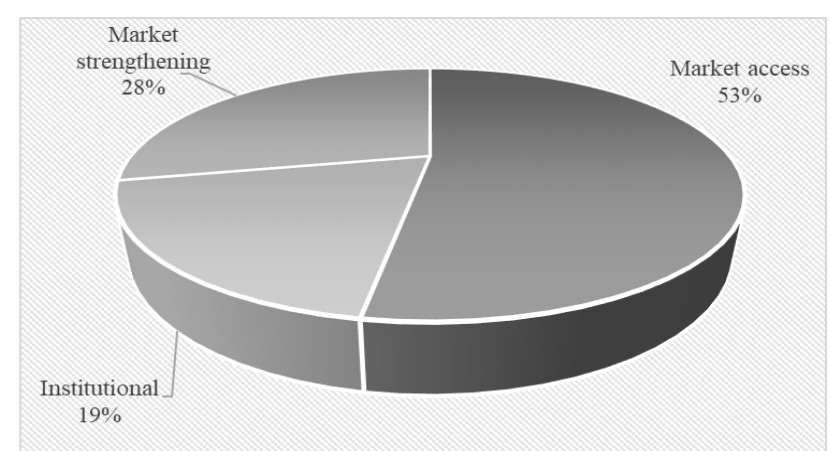

Figure 5. The Priority Portion of Sub Trade and Marketing Criteria

Source: Primary data, AHP processed, 2017

Trade and marketing are an important part of the off-farm level because they are related to the process of determining selling prices which will affect the income of tobacco farmers. The overall marketing chain of tobacco commodities leads to certain manufacturers, entrepreneurs, and exporters as final buyers according to their level, so the nature of their trade is oligopsonism. In this condition the bargaining position of 
farmers is very weak, especially related to the fulfillment of quality, excess inventory and so on. The same thing happens with the position of the entrepreneur and the exporter when facing the final buyer. In terms of trade and marketing, market access is still a top priority with the portion of 53 percent, followed by a market strengthening of 28 percent and institutional 19 percent. Strengthening the market both domestically and internationally is more determined by the development of demands on consumer tastes, especially the fulfillment of health and safety related requirements such as the threshold for pesticide residue content, other hazardous chemicals and the demands of low tar and nicotine content which are currently still the main issues in tobacco trade. Especially, these requirements also work for international market which refers to technical requirements regarding the residual pesticide threshold as listed in the Coresta by which there are more than 100 residual thresholds of active ingredients that are prohibited.

Responding to the demands of technical requirements in the international market, institutional strengthening of all agents in tobacco farming is very important especially in accommodating all the interests of farmers and providing knowledge and skills to farmers and other stakeholders. There needs to be intensive efforts in education and human resource development and strengthening coordination at various levels of tobacco farming in an effort to improve quality and access to market expansion, especially at international level.

The last criterion in the development of tobacco quality is Besuki Na-Oogst, namely program management. The main priority in program management is the management of tobacco quality development programs, followed by the establishment and development of the empowerment of quality formal and informal institutions and funding as showed in the following figure 6.

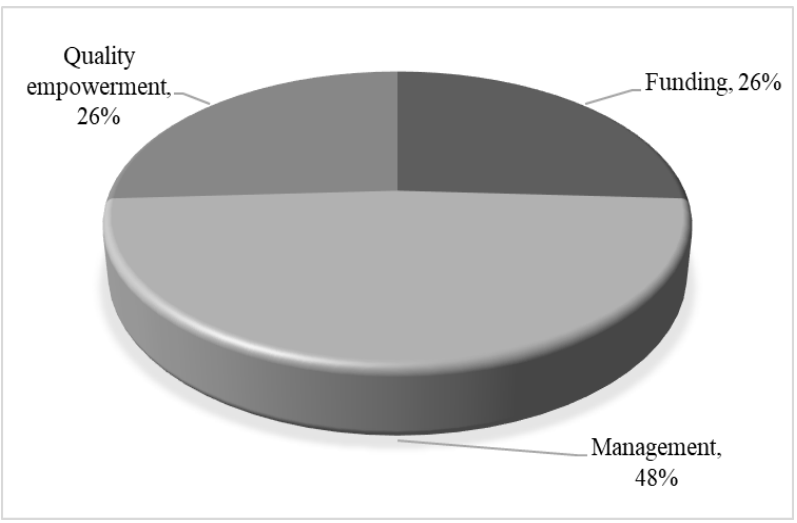

Figure 6. The Priority Portion of Sub Program Management Criteria

Source: Primary data, AHP processed, 2017

Management program is carried out by strengthening institutions, establishing and developing working groups (POKJA), managing revolving funds sourced from cigarette excise. These are aimed at building partnership facilities and fostering farmers as well as building cooperatives to bridge all actors in tobacco farming activities from farmers to exporters through various activities and programs planned. The management of revolving funds accompanied by sharing of funding and quality empowerment must be carried out openly and well planned so that it can create added value in the tobacco farming business. It is also balanced with the intensive socialization and evaluation of program activities to maintain the continuity of the program and development activities of the quality development of Besuki Na Oogst. 
The level of success in implementing the program depends on four (4) factors, namely planning, organizing, actuating, and controlling. Planning as the earliest step in the management process is expected can allocate resources within the organization efficiently to achieve organizational goals. The next step is organizing, this stage is expected to be able to divide the tasks that are appropriate and in accordance with each competency for all those who are active in the organization. Next, organizing can be interpreted as harmonizing different groups of people, bringing together various interests and utilizing all abilities in a particular direction. Good planning and organizing are less meaningful if not followed by the implementation of responsible organizational work. The work implementation must be in line with the work plan that has been prepared. Every organizational actor must work in accordance with the duties, functions and roles, expertise and competencies of each Human Resources (HR) to achieve the defined vision, missions and work programs of the organization. Controlling is not only done by controlling the implementation of organizational programs and activities, but also overseeing, if necessary can make corrections. The monitoring process as part of the control will record the organization's progress towards the expected goals. Through effective supervision of organizational activities, quality control efforts can be carried out better.

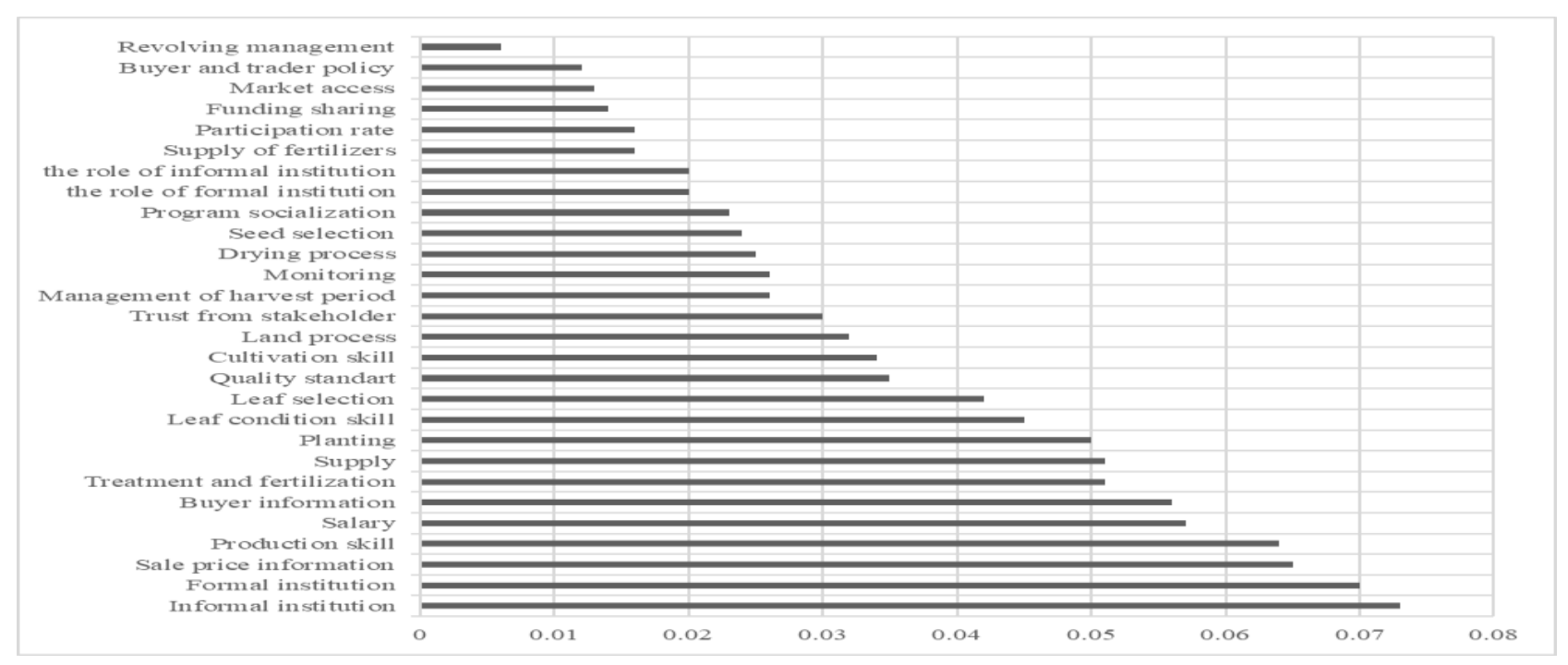

Figure 7. The Portion of Alternative Strategic Priorities in the Development of Tobacco Quality Source: Primary data, AHP processed, 2017

The results of the analysis of alternative strategies, trade and marketing resulted that those three aspects are still the main priorities in the development of tobacco quality in Indonesia. Some top rankings in alternative strategies are the role of formal institutions in marketing followed by management of quality standards, determination of selling prices and market expansion occupying the priorities of all alternatives in the development of tobacco quality. These results are in line with the important role of quality in export commodities in particular in which quality will affect competitive advantage and ultimately improve the welfare of farmers and other tobacco farming actors. Implementation of standards and quality 
should be carried out integrally from upstream to downstream to make them in accordance with the export quality standards required by the export destination countries. Moreover, the upstream sector significantly influences the value of tobacco export quality. If the cultivation process has gone well, it will produce good quality tobacco in accordance with the expected quality standards. The application of tobacco standards and quality is a must in an effort to increase the competitiveness of Indonesian tobacco exports in the international market with increasingly rapid dynamics and increasingly intense competition. Implementation of standards through measurement and testing is needed in order to provide certification by accreditation institutions that have technical competence in producing products to enter competition in the international market. Moreover, quality includes aspects of policy, standardization, control, quality assurance and quality guidance and legislation. Quality control is intended to reduce disability in production based on the causes of disability through the improvement of the production process from the stages of development, planning, production to marketing. This is aimed to provide quality satisfaction for consumers. On the other hand, activities in quality control include setting standards, assessing conformity with standards and carrying out test procedures.

\section{CONCLUSION}

Besuki Na-Oogst Tobacco has a strategic role in international trade in twoway traffic commodities because of its fancy product in capturing market. Quality standardization is an absolute requirement in determining the success of the competitiveness of plantation commodity exports that have high selling value.

The success of Besuki Na-Oogst tobacco cultivation governance as a quality and exportoriented product is not only determined by good cultivation techniques but also needs to be supported by institutional patterns that are present among business actors and also policy makers, in this case the government. Institutional strengthening in Besuki Na-Oogst tobacco cultivation must be carried out integrally from upstream to downstream, from on-farm to off-farm which involves every component and space of interaction in each link.

Priority factors in the strategy for developing the quality of Besuki Na-Oogst tobacco are human resources, followed by tobacco cultivation, trade and marketing and program management. These factors are reinforced by the importance of institutional formation both from the formal and informal sectors.

\section{REFERENCE}

Abdallah, F. (1972). Can Tobacco Quality Be Measured? Lockwood Publishing Co. Inc. New York.

Alegantina, Sukmayati. (2017). Determination of Nicotine

Levels and Characteristics of Tobacco Leaf Extract (Nicotiana tabacum L.). Journal of Health Services Research and Development, Vol. 1 Number 2.

Arifien, Moch. Samsul. (2013). Tobacco at the Crossroads. East Java Province Plantation Office.

Chen, H. sheng, Liu, G. shun, Yang, Y. feng, YE, X. feng, SHI, Z., (2010). Comprehensive Evaluation of Tobacco Ecological Suitability of Henan Province Based on GIS. Agric. Sci. China 9, 583-592. doi:10.1016/S1671-2927(o9)60132-2.

Claudia, C., Khumalo, M., Claudia, C., Khumalo, M. (2013). Can Farmers Diversify from Growing Tobacco in Zimbabwe?

Creswell, J.W. (1998). Qualitative inquiry and research design: Choosing among the five traditions. Thousand Oaks, CA: Sage. 
Djajadi. (1999). Prospects for Organic and Biological Agriculture in Tobacco Cultivation. In Proceedings of the Workshop on Tobacco Technology. Tobacco and Fiber Plant Center. Jakarta

Djajadi. (2008). Besuki-NO Cigar Tobacco: Development of Areas and Problems in South Jember. Perspective, 7 (1): 12-19.

FAO. (2003). Issues in the Global Tobacco Economy: Selected case studies. Rome: Food and Agriculture Organization of the United Nations.

Feirman, S.P., Glasser, A.M., Rose, S., Niaura, R., Abrams, D.B., Teplitskaya, L., Villanti, A.C. (2017). Computational Models Used to Assess US Tobacco Control Policies. Nicotine Tob. Res. 29, 19-26. doi:10.1093/ntr/ntxo17Geo-Information 5, 99. doi:10.3390/ijgi506oo99

Keyser, J.C., Juita, N.R. (2005). Smallholder Tobacco Growing in Indonesia: Costs and Profitability Compared with Other. HNP Discuss. Pap. Economics.

Miles, M., \& Huberman, M. (1994). Qualitative data analysis: A sourcebook of new methods (2nd ed.). Newbury Park, CA: Sage.

Negri, M., Porto, G.G. (2016). Burley tobacco clubs in Malawi: Non market institutions for exports. Int. Econ. 146, 85-107. doi: 10.1016/j.inteco.2015.11.004

Nezhad, A.S., Rezaei, A.Z. (2015). Application of Analytical Hierarchy Process (AHP) in productivity of costs of Quality 184-189.

Nur, Yudha Hadian and Devi Apriana. (2013). Competitiveness of Local Virginia Tobacco in the Domestic Market. Trade Research Scientific Bulletin. VoL.7 No.1, July.
Onder. (2010). The Economics of Tobacco Use \& Tobacco Control in the Developing World. Niger. J. Physiol. Sci. $25,81-86$.

Rangkuti, F. (1999). SWOT Analysis of Technique to Operate Business Cases. PT Gramedia Pustaka Utama, Jakarta.

Rochman, F. and Suwarso. (200o). Local Temanggung Tobacco Cultivar and Efforts to Repair it in Temanggung Tobacco. P. 71-86 Monograph Balittas No. 5, Research Institute for Tobacco and Fiber Plants Malang.

Rokhmah, D. anf K., (2014). Risk Factor Analysis of Green Tobacco Sickness (GTS) and the handling method on Tobacco Farmers 1, 20-29.

Romeijn, H., Faggian, R., Diogo, V., Sposito, V., (2016). Evaluation of Deterministic and Complex Analytical Hierarchy Process Methods for Agricultural Land Suitability Analysis in a Changing Climate. ISPRS Int. J.

Saaty, T.L. (1980). The Analytical Hierarchy Process. McGraw Hill Inc. New York.

Sholeh, M., A. Rachman, and Machfudz. (2000). Effect of combination of KS, ZA and Urea fertilizers, and N doses on the quality of besuki NO cigar tobacco in Jember. J. Penel. Tan. Industry 6 (3): 80-87.

Soetriono et al. (2014). Tobacco Agribusiness Besuki NaOogst: Overview of Agricultural Economics. Surya Pena Gemilang.

Tso, T.C. (1972). Physiology and biochemistry of tobacco plants 140 p. Stroudsburg, Pa: Dowden, Hutchinson and Ross Inc.

Zhang, J., Su, Y., Wu, J., Liang, H. (2015). GIS based land suitability assessment for tobacco production using AHP and fuzzy set in Shandong province of China. Comput. Electron. Agric. 114, 202-211. doi: 10.1016/j.compag.2015.04.004. 